Chapter 2:

(E)Merging Practices in Post-1989 Central European Theatre(s) 



\title{
Emerging Postdramatic Aesthetics and Shakespeare in Hungarian Theatre
}

Kornélia Deres

\begin{abstract}
The essay aims at examining the ways postdramatic aesthetics meet Shakespearean plays in Hungarian theatre. Offering a context for postdramatic strategies in European theatre practices and touching upon its regional differences, a main goal is to analyse how postdramatic strategies affect the schemes of interpretation and reception in the Central European geopolitical region. Presenting two case studies of staging Romeo and Juliet on Hungarian stages between 1996 and 2019, the article argues that a new relation of visuality, performativity, and textuality, emerging in these productions, can lead to rediscovering and reinterpreting Shakespearean dramas after 1989.
\end{abstract}

\section{Key words}

postdramatic theatre, Hungarian theatre history, intermedial dramaturgy, visuality and textuality in theatre, Romeo and Juliet 
During recent decades in Central Europe everyday cultural practices have been increasingly formed by the rise of media technologies, which have also played an important role in apprehending the multi-perspective and intermedial nature of human perception. The fall of the supposedly linear and teleological mode of comprehending and representing reality has affected contemporary theatrical languages as well. Accordingly, the experience of media culture has created a specific type of aesthetics in European theatre, often described as postdramatic. The present essay aims at examining ways that postdramatic tendencies appeared in Hungarian theatre after 1989, particularly in productions of Shakespeare. The selected examples describe various strategies in using Shakespearean texts (including adaptations and new translations) in terms of the overall relationships to the textual element as opposed to the purely visual, acoustic, and kinesthetic. A common feature of all the productions examined is the fact that each shows how word-based texts are becoming more and more open to changes, associations, and allusions.

My research questions focus on how postdramatic strategies affect schemes of interpretation and reception: how they invite in new audiences, and how a new relation of visuality, performativity, and textuality is emerging in postdramatic productions, all of which have led to reinterpreting Shakespearean dramas after 1989. First, I will provide context for the term postdramatic theatre along with regional differences, as well as some examples of postdramatic Shakespeare productions in Europe. From relatively recent Hungarian theatre practice, I will then offer two case studies of staging Romeo and Juliet, one from the year 1996, the other from 2019, both of which represent a different set of postdramatic strategies in terms of textual and theatrical methods. Finally, I will also touch upon how audiences and critics reacted to these two productions in particular to describe more generally the reception of these emerging theatrical languages.

\section{Postdramatic tendencies and regional differences}

The term 'postdramatic theatre' was first introduced in 1987 by the Polish theatre scholar Andrzej Wirth to depict contemporary theatre trends (KOVACS 2017: 244). However, the concept did not become widespread until the 1999 publication of Postdramatisches Theater by Hans-Thies Lehmann. The German theatre theorist summarised his stance in the book's Prologue as follows: 'the spread and then omnipresence of the media in everyday life since the 1970s has brought with it a new multiform kind of theatrical discourse that is here going to be described as postdramatic theatre' (LEHMANN 2006: 22). Using this umbrella term, Lehmann set out to offer a panorama of new theatre aesthetics affected by the influence of mass media, popular culture, and new technologies.

Postdramatic theatre can be seen partly as a reaction to our everyday experience of living in an immersive multimedial environment, which results in the negation or at least dissipation of linear, teleological, progressive modes of storytelling, perception, and representation. Postdramatic theatre does not reinforce the primacy of the text. 
This can be opposed to the 'dramatic tradition', in which 'staging largely consisted of the declamation and illustration of written drama. Even where music and dance were added or where they predominated, the "text", in the sense of at least the imagination of a comprehensible narrative and/or mental totality, was determining' (LEHMANN 2006: 21). In postdramatic theatre, the role of the text begins to morph from a basis or origin of a future theatre production into a material open to subjective interpretations, or to instances of free dialogue with other textual and medial forms. It is important to note, however, that even when the term 'postdramatic' is opposed to the dramatic paradigm, it is more productive to imagine the relations along a continuum rather than in simple binary opposition, as most theatre productions present both postdramatic and dramatic elements.

Thus dramatic texts themselves do not necessarily disappear in postdramatic productions, which is a common but highly narrow (mis)interpretation of Lehmann's theory. Nevertheless, the hierarchical status of the word-based text is unquestionably altered, allowing visual, acoustic, and corporeal elements to gain more importance. This also means that it is no longer linear textual logic which characterises these types of productions. Instead, the model of the postdramatic includes fragmentedness as well as shifting focuses, associations, and partiality; this is the case both in theatrical representations and theatre production (see for instance the metaphor of the 'production line' by CONSTANTINIDIS 1993). In a broader sense, the perception of reality is altered and commented upon. The postdramatic thus relies on the awareness that reality in a media society can no longer be modelled in authentic ways through the logic of the drama, i.e., featuring a coherent story line, human-centred conflicts, and/or a selfcontained fictional world.

Lehmann argued that the rise of media society began in the 1970s. Still, at that time the concept can be seen to apply only to Western-style democracies, not to Central and Eastern European Socialist states, where global media culture did not fully arrive until two or three decades later. Consequently, the remains of the cultural, mental, and social claustrophobia caused by state Socialism were confronted with images of freedom at the same time as the boom of the media society was overtaking this geopolitical region. In the post-Socialist area, theatre aesthetics before and even for years after 1989 were highly dominated by realism, and as a consequence, a text-based dramatic perspective influenced the routines of audience reception and interpretation. However, a number of artists, especially those not supported by the authorities during the Socialist regimes and who were interested in challenging realistic conventions, had offered theatrical examples of non-linear dramaturgy, body-based performances, spiritual practices, audience-actor interactions well before 1989. These instances can be seen as the prehistories of later postdramatic trends.

Examples of these multivalent phenomena include: in Poland regionally influential artists like Grotowski and his poor theatre (1960-1970s) and Kantor and the 'Theatre of Death' (1970-1980s); theatre collectives in Hungary such as Kassák Ház Stúdió [Kassak House Studio] and later Lakásszínház [Apartment Theatre] or Orfeo csoport [Orfeo Group] (1960-1970s); in the former Czechoslovakia Divadlo Na zábradlí [Theatre on 
the Balustrade], Bílé divadlo [White Theatre], and the Semafor Theatre (1960-1980s) in Prague, Husa na provázku [Goose on a String] in Brno, and the On Korzo Theatre in Bratislava (1960-1970s). All of these groups (re)presented various non-realistic, experimental theatrical styles, yet at the time they could offer no real alternative against drama-based realism and its interpretative conventions; their audiences were usually limited, and in many cases the productions were also banned because of political reasons. This lack of recognition, furthermore, also had an effect on the critical reception of post-1989 non-realist theatre productions. Reviewers often listed elements they felt to be lacking, such as coherency, well-built dramaturgical lines, and professional acting styles, all of which consciously or unconsciously refer back to the medial and institutional structures of drama-based theatrical realism.

I am not suggesting here that the Central European region can be treated as one unified and identical bloc in terms of theatre history, since the regional differences have resulted in divergent contemporary theatrical landscapes. For instance, the Polish scene remains unquestionably more open to postdramatic effects in theatre than that of Hungary. Still, due to the above-mentioned dominance in the region of realism both in creation and reception, a number of recent theatre initiatives have not been able to enter into mainstream theatre practice, or become recognised by critics.

In the meantime, in many countries of Western Europe and generally in Germanspeaking areas the rise of postdramatic productions generated interpretative strategies which were more open towards fragmented and fractured theatre productions, including those connected to Shakespeare's works. Therefore, audiences (including general spectators and critics) had both more time and opportunity to encounter theatre aesthetics which questioned the primacy of word-based text. Here I will provide three examples which describe divergent postdramatic strategies in order to create a historical and aesthetical context for further investigations. The examples will show how the textual element came to be reshaped by visuality, corporeality, intermediality, as well as by collective methods of creation.

In 1997 the well-known Italian collective Societas Raffaello Sanzio, led by Claudia and Romeo Castellucci, premiered their piece Giulio Cesare. ${ }^{1}$ The production was based on the Shakespearean drama Julius Caesar, but powerfully transformed conventional interpretations through the incorporation of radical corporeal aesthetics or somaesthetics (SHUSTERMAN 2012). The production was based upon the presentation of bodies usually neglected, if not excluded entirely, from Western stages, as well as on the effects of medical technologies. Not only were normative body images challenged, but the very structure of received discourses on the body were continuously subverted (BOUCHARD 2008: 102). For instance, an overly obese body incorporated Cicero, presenting a massive figure which literally turned his back on the killing of Caesar. Opposed to this

1 Based in Cesena, Societas Raffaello Sanzio is a reputed Italian collective founded in 1980. Since then it has been led by siblings Claudia and Romeo Castellucci, who consistently seek out subversive techniques to represent certain themes, texts, and images in theatre. The collective radically re-forms received notions of theatre by deconstructing the classical hierarchy between words and bodies on stage, thus opening up conventional representational systems. 
image, Brutus and Cassius were played by two anorexic-looking female actors in the second act, their fragile, skeleton-like frames acutely embodying the idea of being 'eaten up by guilt' (CARDY 2012). Julius Caesar, on the other hand, was seen through a deteriorating, disturbingly weak, naked old body. Last but not least, Mark Antony was played by an actor who had a laryngectomy, with parts of his voice box surgically removed. This choice highlighted how the trace of this surgical action, the wound, the black hole on the front of the actor's neck was vitalised by speaking. The audience could also witness another character putting an endoscope into his nose, mouth, and throat while close-ups from the interior of his body were projected behind him, mostly notably of his functioning larynx. Hence the bodies on stage were not handled as neutral mediators of words, but as meaning creators which sometimes had to struggle to perform language (BOUCHARD 2008).

A different strategy may be observed in German director Thomas Ostermeier's Hamlet of 2008. ${ }^{2}$ Here the impact of media culture was more than obvious, since Hamlet as played by Lars Eidinger often appeared as a film director with a hand-held camera who obsessively recorded his surroundings including family and friends, finding evidence for their guilt or innocence. In this way, Hamlet himself became both the agent and the lens through which the action could be seen (MANCEWICZ 2014: 100), turning the whole stage into the mindspace of the main figure (REYNOLDS 2017: 263). The theatre space was dominated by a huge curtain of gold chains serving as a screen upon which mediatised representations of the characters appeared. Consequently, film images from various film genres and performative styles as representations of reality were shown as ruling the imagination of the leading character. As Aneta Mancewicz (2014) has pointed out, although this also resembled the use of video in various Hamlet adaptations, such as Michael Almereyda's film and Greg Doran's 2008 staging with the Royal Shakespeare Company, in Ostermeier's case the video also formed a perceptive disconnection between the 'live and mediatised appearances' on stage. This effect is also echoed in the various masks the characters put on, both literally and metaphorically (MANCEWICZ 2014: 100-101). Ostermeier applied a new translation and adaptation by Marius von Mayenburg, resulting in a colloquial and sometimes even vulgar textual expression. Although the director followed a relatively linear storyline, it was constantly and violently interrupted by various performative elements such as shorter musical scenes, performance clips (echoing British in-yer-face aesthetics), physical tricks (at the funeral, or the feast), interactions with the audience as well as allusions to various film genres. The production was set along the lines of an earlier Shakespeare adaptation by Ostermeier (together with choreographer Constanza Macras) of $\mathrm{A} \mathrm{Mid-}$ summer Night's Dream in 2006, which brought the story to a 1960s party lounge with many mainstream music tracks, but less of the original text, creating a 'highly contemporary rock version' of the play (CARLSON 2009: 176).

2 Born in 1968, Thomas Ostermeier is an internationally acclaimed German director associated with intermedial and physical theatre aesthetics. He started his career as director-manager of the Baracke, then joined Deutsches Theater. Since 1999 he has been working at the Schaubühne as a member of the artistic direction team. In 2011 he received the Golden Lion of the Venice Biennale for the entirety of his work. 
Thirdly, a mixture of documentary practices and playing with Shakespeare could be found in the German performance collective She She Pop's 2010 premiere of Testament. ${ }^{3}$ The production was based on King Lear, however, this served merely as a starting point for further associations and discussions. Above all, the collective sought to examine the central problem of the father and daughter relationship in the drama. To this end, they also investigated this important issue in their own lives, creating a specific autobiographical production in which, besides textual fragments from King Lear and other media forms (songs, films), the performers even put their own fathers on stage and created various dialogues and scenes with them. The production also staged various ways of connecting Shakespeare's drama to everyday experiences, as Lyn Gardner pointed out: 'The scene where Goneril dismisses Lear's 100 knights becomes a sharply entertaining visual exercise in which a daughter tries to accommodate her father and his thousands of books in her small apartment' (GARDNER 2014). Furthermore, Testament followed the five Shakespearean acts to stage five issues regarding taking care of aging fathers: 'inheritance, housing in old age, fear of physical decay, the possibility of reconciliation between the generations, and, at the very end, the inevitability of death' (SCHÄFER 2019: 127). The production thus called attention to its deconstructive strategy towards the text, which allowed the collective to reshape and rediscover a piece in the European dramatic canon and use it to create a contemporary dialogue between the generations.

The above mentioned examples represent but a small overview of various postdramatic strategies in dealing with the Shakespearean oeuvre in European theatre: while Societas Raffaello Sanzio used the physicality of the bodies to perform corporeal aesthetics in Julius Caesar, in which materiality becomes the focus, director Thomas Ostermeier made use of the effects of home video culture in Hamlet and, consequently, the codes of representation and modes of presence were connected to film genres and video technologies. She She Pop, on the other hand, introduced a documentary practice through which the creators' associations and their own stories are placed alongside King Lear, resulting in a collaborative working method. Nevertheless, the relationship of the three productions to the dramatic text also includes important similarities.

In her article on Austrian postdramatic texts, Teresa Kovacs presents the image of the 'ruin' (KOVACS 2017: 248-253), a figure which can also help offer a productive context for postdramatic Shakespeare productions. Postdramatic performances usually handle canonical dramatic texts as ruinous documents, ${ }^{4}$ texts which are to be completed

3 She She Pop is an internationally acclaimed performance group founded in 1998 as a women's performance collective by graduates of the Institute for Applied Theater Studies in Gießen. The initial aim of rejecting male dominated power structures of the hierarchic culture industry remains a key element in the collective's work, but soon after their start they incorporated males into the group. Their works are known for challenging the boundaries between private and public, classical material and their own biographies, as well as audience and performer.

4 It is important to note that Shakespearean texts have never been fixed or stable entities, e.g., text cuts (and less often insertions) are commonly made even in productions attempting to stay as faithful as possible to a particular received textual version of the drama. Despite the rise of canonical versions, in the early modern period different quarto editions recorded various versions of playtexts, and beginning in the 
and challenged by other materials such as other texts, songs, movies, performative traditions, etc. Consequently, the process of reception seems to be most important, namely, the ways and methods in which the creators - individuals or groups of artists, or in some cases the entire collective, sometimes primarily directors and dramaturgs (re)interpret, (re)shape, and (re)discover the dramatic texts. This process generally results in the presentation of fragmented intertextual and intermedial networks on stage. Not surprisingly, postdramatic aesthetics are usually, and especially in Central Europe, connected to a relatively younger generation of theatre makers who have already been socialised in the media society, which means that the codes, conventions and forms of visual mass media (films, television shows, video games, etc.) have become the core of their perception of the world, and they easily integrate this experience into their theatre works.

\section{Hungarian theatre and postdramatic Shakespeares}

Hungarian theatre is connected to the Shakespearean oeuvre in many respects, starting from the programmes of the first established Hungarian theatres in the $19^{\text {th }}$ century in Pest-Buda. Regarding the $20^{\text {th }}$ and $21^{\text {st }}$ centuries, the relevance of the author in the theatre does not seem to have diminished. According to the database of the Hungarian Theatre Museum and Institute, between 1950 and 2019 there were 839 premieres of Shakespearean works by Hungarian theatre companies both within and outside the borders of the country (SZABÓ 2019: 56). During this time period the most popular dramas included A Midsummer Night's Dream, Hamlet, Twelfth Night, and Romeo and Juliet, all of which were staged most often in the early 1960s and the 2000s, increasing right after 1989 (SZABÓ 2019: 57). (For a detailed account of the tendencies of the production and reception of Shakespearean dramas in Hungarian theatre, see MÜLLER's article in this collection.

Although there are few theatre artists who have committed themselves exclusively to postdramatic aesthetics as well as to Shakespeare within Hungarian theatre, several working methods can be observed in the most relevant theatre makers and collectives. These strategies include collective text creation (Moving House Company), new adaptations (dir. Dániel D. Kovács), intertextual bricolage (HOPPart Company), and thematic improvisation (dir. Viktor Bodó). In the following section I will focus on two instances of postdramatic strategising in Hungarian theatre, each of which shows a different process concerning the textual element and the Shakespearean tradition. Both stagings dealt with Romeo and Juliet, but while the collective method of theatre making by Mozgó Ház Társulás [Moving House Company] resulted in a collection of set pieces representing love in various media, Viktor Bodó's directorial theatre presented the drama as

$17^{\text {th }}$ century folios recorded sundry versions of the plays as well. So we can say that Shakespearean texts are ruinous in themselves, representing the predramatic paradigm in terms of both theatre and dramatic practice. (I would like to thank Natália Pikli, who pointed out the ruinous, uncertain nature of $16-17^{\text {th }}$ century Shakespearean playtexts.) For more details see (PIKLI 2013: 130-132). 
a chaotic hallucination full of intermedial effects. The case studies will also point out that, although the artists attempted to deconstruct many elements of dramatic theatre, audiences often responded with mixed feelings to these adaptations.

\section{Love is love: the Moving House Company and collective theatre making}

As mentioned above, the experience of media culture began affecting Hungary and the region in the 1990s, however, its direct effect on theatre-making became visible only through a small number of artists and collectives. One of the most relevant early collectives among these was the Moving House Company, an experimental theatre group active between 1994 and 2002. The founding actors of the company were in their early $20 \mathrm{~s}$ at that time and described themselves as having grown up during the Kádár regime (the so-called soft period of state Socialism in Hungary between 1956 and 1989), becoming adults around the change of the regime. The group was joined by director László Hudi, an important figure in the Hungarian independent theatre of the 1980s, a member of many well-known experimental collectives as the Monteverdi Wrestling Circle and the Sign Theatre. Hudi also spent several years in France, and as a director he built on this experience with a variety of French theatre aesthetics and physical theatre, which differed greatly from the Hungarian realist tradition.

In 1996 the theatre collective premiered one of their earliest pieces, a production originating from Romeo and Juliet, in an experimental, unique, and energetic way. Here Shakespeare's text represented a common source of knowledge, a common basis for cultural understanding as well as for further dialogues for the artists to engage with. Consequently, the show offered a number of medial and performative layers, integrating sequences of dialogues and monologues, choreographed dances, songs from the 1960-1970s, with all of these sequences based on the theme of how love could be spoken, represented, and staged according to various European traditions. The scenes thus presented many couples enacting many Romeos and Juliets, posing questions of love and death, male and female gender stereotypes as well as physical and emotional intimacy. As one of the reviewers summed it up:

Resisting the (acting) traditions connected to Tamás Major ${ }^{5}$ and Miklós Gábor, ${ }^{6}$ the actors did not intend to get into the heads of Romeo and Juliet, the lovers they were representing. They

5 Tamás Major was one of the most influential actors, directors, and theatre managers in the period of Hungarian state Socialism. He started his career as a member of the National Theatre, serving as executive director between 1945-1962, and remaining one of its leading directors until 1978. He was also a member of parliament in the $1950 \mathrm{~s}$ and $1960 \mathrm{~s}$. Major contributed to the foundation of the Katona József Theatre in 1982.

6 Miklós Gábor was an influential Hungarian actor in Socialist Hungary and a member of many representative theatre companies such as the National Theatre and the Madách Theatre. He was often described as an intellectual actor, a master of psychological acting, becoming an icon in Hungarian culture as well. Gábor was known for his memorable Hamlet in 1962. 
neither interpreted the motivations of the characters, nor did they add a historical context to their actions; what is more, important characters such as Mercutio and Tybalt were absent. The actors on stage stood for simple people in love, who feared death and were fragile, just like their spectators. (VAJNA 1996: 101)

My claim is that this experimental Shakespeare production by the Moving House Company set out the problem of how simultaneous performative traditions (including Shakespearean drama, love songs, dance theatre, soap operas, romantic films, etc.) affected conventions of representation and models of perception. This claim, however, calls for a perspective which allows the examination of theatre within a complex media context with respect to how theatre is able to stage other medial forms. By integrating the aesthetics, conventions and technologies of various forms of media, theatre as a hypermedium is able to address the different modes and techniques of human perception, and thus offer an in-between mediality for the spectators as suggested by Kattenbelt (2006), Balme (2004), and Boenisch (2003).

In general, the Moving House Company's productions aimed at staging how visual media and various performative traditions, including music, film, television, and other genres of pop culture, have (re)formed the concept of theatre. The group often initially based their pieces on well-known dramatic stories, but these texts were mere starting points which made further textual, medial, and performative allusions possible. Many of their works earned international success, including various prizes at a number of theatre festivals, e.g., at the European Festival, the International Festival of Sarajevo, and the San Antonio Festival. Their productions were aired by ARTE, 3sat and Deutsche Welle TV; in addition, they were also the first Hungarian group to perform at the Avignon Theatre Festival in 2000 and 2001.

Despite this renown abroad, the majority of Hungarian critics, including the most established theatre reviewers of the time, labelled them as amateur or incomprehensible, showing no memorable acting technique or production values (see CSÁKI 1999; KOLTAI 1999; MOLNÁR GÁL 1999; SÖREGI 2002). In my opinion, this stemmed from the fact that most of the reviewers were locating the company's work within a text- and actor-based dramatic paradigm in which the lack of well-built dialogues and a closed, coherent fictional world seemed a clear and major deficiency. As a consequence, a unique situation arose in terms of theatre history: the group had obtained international acknowledgement, but at the same time rejection or miscomprehension in terms of Hungarian critical reception. During the past decade or so, however, the collective has been rediscovered and discussed by theatre historians and a re-evaluation of their work has begun (see IMRE 2009; PERESZLÉNYI 2014a, 2014b; DERES 2016).

While Moving House's Romeo and Juliet did evoke Shakespeare's drama, the production treated the text and the dramatic story as already extremely well-known, and therefore as ideal material with which to open a wide range of associations using not only widely contemporary but also personal interpretations. Shakespeare's Romeo and Juliet was taken as the finest representative of a love story, and the actors used it as a starting point; for example, during rehearsals they wrote short poems using interesting 
expressions from the drama (PERESZLÉNYI 2014a). Their improvisations during performances were based on these short poems. The actors were able to continuously reflect on the situation of being on stage reiterating one of the most well-known romantic tales of all time, and thus were able to incorporate their own thoughts and experiences. The production made use mainly of cabaret dramaturgy, i.e., a series of loosely connected scenes interspersed with various musical and performative elements.

The dialogues and monologues were accompanied by choreographed dance pieces which were also based on the poems the actors had composed during the rehearsal period. In addition, some scenes were based on famous Hungarian love songs from the 1960-1970s which served as a local cultural connotation attached to the representation of love. The scenes, however, were interconnected not only on a thematic but also a structural level. For instance, one Romeo (Balázs Vajna) carried out a monologue on the topic of mortality, grotesquely exaggerating the fact that all people will eventually die whether they like it or not. Parallel to this, one Juliet (Réka Gévai) was on her knees pouring water under her eyes in an imitation of the act of crying, declaring that she did not want to die. In the meantime, another Romeo (László Szabó) came on stage to imitate dying in an exaggerated way. Another scene focused on another Juliet (Erika Pereszlényi) who complained about the future situation when she would have to stand naked in front of her Romeo, and her fear that not only would she be ugly, but Romeo would be as well.

The structure of the production clearly shows how the interconnectedness of various performative traditions (for instance, Brechtian acting style, dance theatre, couplet songs, cabaret) can reinvent Shakespearean drama by offering interpretations that reflected the experience of the generation who entered adulthood after the change of the regime. The production also called attention to the role of the spectator as an active agent in making the different visual and acoustic layers work together. Unlike dramabased theatre, this strategy highlighted various modes of perception and never let the spectators forget that the way we structure the world is always a question of historical and cultural experience. This Romeo and Juliet offered the possibility to rethink perception itself and thus imagine a radically recharged agency of the human self, actor and spectator alike. The Moving House Company's structuring and handling of materials on stage resembles the techniques of such experimental collectives as the Wooster Group, building on the fragmented nature of perception complemented by presentations of various interrelated ways of sensation and experience. By its use of collective theatre making methods, the Shakespeare adaptation by Moving House fostered a dialogue among the canonical love couple and the rapidly changing cultural horizons.

\section{Romeo on drugs: The Shaxpeare Wash of Kertész Street}

The previous case demonstrates how postdramatic strategies in Hungary were introduced at independent or alternative theatre sites. Although later these strategies reached established institutions as well, they are usually employed in relative isola- 
tion, connected to certain directors. Among the small number of theatre artists engaged with postdramatic aesthetics in Hungary, an important figure is Viktor Bodó. The director currently works more in German-speaking countries (Austria, Germany, Switzerland) than in Hungary, but he unquestionably maintains strong bonds both to independent theatre sites (he was manager of the collective Sputnik Shipping Company between 2008-2015) as well as to established theatres in Budapest as he regularly works at Katona, Víg, and Örkény (for details see PIKLI's article in this collection). Starting his career in the late 1990s, Bodó's work represents a unique theatrical language of the past two decades, integrating associative improvisations, multi-perspectivity, a conscious use of pop culture quotations as well as technological media conventions.

These characteristics connect Bodó's theatre to so-called 'cool fun' aesthetics, known from German performance trends, which seek

[...] an adequate expression for a saddened but also desperately psyched-up sense of life. Theatre here mimics and reflects the omnipresent media and their suggestion of immediacy, but at the same time searches for another form of a sub-public. Behind an ostensible exuberance, melancholia, loneliness and despair become perceivable. This conspicuous variety of postdramatic theatre often finds its inspiration in the patterns of television and film entertainment and makes references (irrespective of quality) to splatter movies, quiz shows, commercials and disco music, but also to a classical intellectual heritage. At the same time this theatre registers the state of mind of its mostly young spectators - their feelings of resignation, rebellion and sadness, and their desire for happiness and to live life intensely. (LEHMANN 2006: 118)

Consequently, my claim is that Bodó's 2019 Romeo and Juliet adaptation at the Örkény Theatre under the title The Shaxpeare Wash of Kertész Street can be productively interpreted from the perspective of intermedial fractures. In most of his works, the director stages reality as a chaotic labyrinth, perceived by an extended, surreal state of the mind through the use of moving images, intermedial allusions, pop culture references, and other film conventions. In these fictional worlds the vast number of unexpected elements that emerge ruin the possibility of a unified, coherent, and strict dramaturgy. Early critical responses from established critics to Bodó's work featured expressions such as 'sketches', 'inconsistencies', 'eclectic', 'twaddle', 'roughness', 'disintegration', 'bluff' (see CSÁKI 2003; KARSAI 2005; KONDOROSI 2005; MOLNÁR GÁL 2006; TARJÁN 2007). Most critics seem to have noted a lack of certain conventions of realism by which speech, gesture, and movement on stage should consistently represent inner psychological content.

Whereas Moving House treated Romeo and Juliet as material for their own subjective interpretations and wide-ranging associations, Bodó based his production on an adaptation by another author. His colleague, poet and playwright Péter Závada rewrote the whole piece by relocating the story to contemporary Hungarian reality. As a result, the two families and their allies appeared as rival criminals in the $7^{\text {th }}$ district of Budapest, using a car wash for washing not only cars but money laundering as well. This created an environment full of verbal and physical aggression. Consequently, the young lovers 


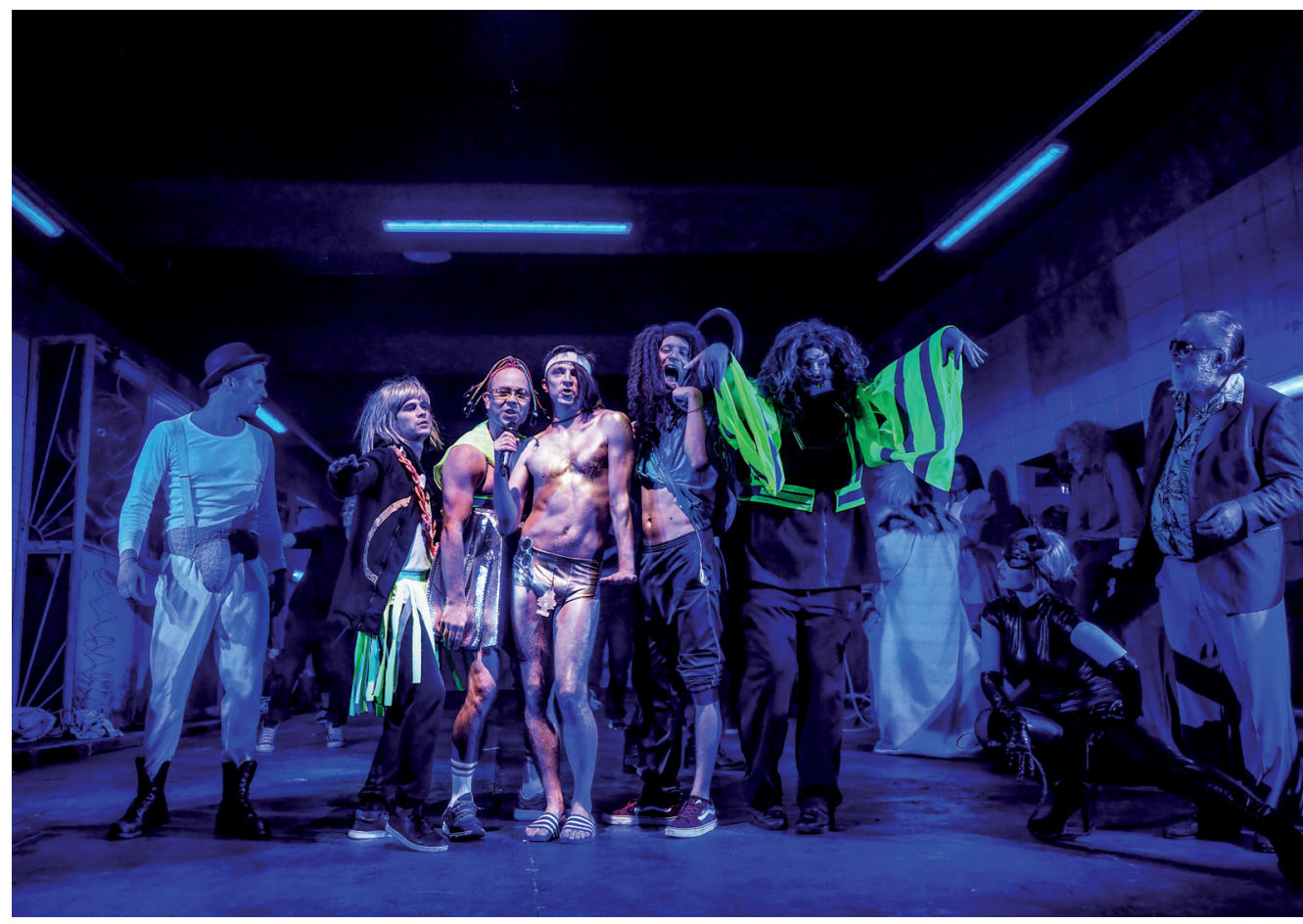

Fig. 1: Party scene in The Shaxpeare Wash of Kertész Street. Photo: Judit Horváth. Örkény Theatre.

met at a psychedelic party: Romeo was suffering from drug addiction, and Juliet stood in the shadow of a forced marriage to a politician. In addition to the alteration of the story elements, the adaptation consciously annihilated the poetical layer of the text, turning towards a much bolder style with slang and argot. Nevertheless, Bodó's staging was not a text-based performance. Despite the fact that the adaptation by Závada was created for this premiere, the final production was only partly based on the play text, and partly on improvisations by the actors, resulting in completely new scenes.

Overall, Bodó's view of the material suggested a reality full of violence, tempered with minor sparks of emotion, which were being extinguished due to the basic rules of the represented environment. The director made use of the conventions of film (slow motion, cutting technique, thematic songs) in various scenes, which allowed him to comment on how the world is perceived under the effect of various drugs. Moreover, the production, especially the first act, was based on a specific intermedial dramaturgy, one which did not eradicate the story line, but presented a series of surrealistic events through which an unstable world was seen as falling apart. The production could be seen as a de(con)struction of a unified narrative on stage, combining various medial conventions, forms, and materials, including, for example, a wide range of music by international (Iggy Pop, Radiohead, Aerosmith, Freddie Mercury, Eric Clapton, Massive Attack) and Hungarian performers (Charlie, Ákos, Jimmy Zámbó, Bizottság). 
In addition, in the light of the new title, Shakespeare was polished, quite literally, in the opening scene: a very iconic Shakespeare figure with recognisable clothes, hairstyle, and ruff played by Zsolt Máthé was being washed while he gave a rap solo not only on the story but on the production's relation to previous European textual and performative traditions as well as Hungarian translations:

It's the same old story, but Mr. Nádasdy, ${ }^{7}$ sorry,

We flipped the original: instead of noble, it's proley.

Some other things too that you won't get though:

Iambs, blank verse, folio, quarto.

The Lord Chamberlain's Men, no, not really,

Di Caprio's cool though, and of course Zeffirelli (ZÁVADA 2020). ${ }^{8}$

The highly allusive text of the production, the various generic conventions, and the spectacular visuality together created an accelerated tempo on stage through which Shakespeare could come into contact with a number of layers of Hungarian contemporary reality. Critical reactions were, however, mixed: many praised the dynamic energy of the performance and connection of Shakespeare's classic to pop culture, ${ }^{9}$ whereas others were displeased by the lack of poetic language and the dominating revue style.

Handling the Shakespearean oeuvre in a manner that is open not only to pop culture references but to wide and wild allusions and iterations from various medial forms and genres characterised the staging by Bodó. The theatrical language connected to the director greatly affected many younger Hungarian directors including Dániel D. Kovács and his productions of Twelfth Night (2016) and A Midsummer Night's Dream (2017), as well as Attila Vidnyánszky Jr.'s staging of Twelfth Night (2019).

As a consequence, it seems that postdramatic strategies in theatre are attached to a specific mode of perceiving reality through various medial genres, conventions, and representations. A performance built on postdramatic elements thus entails more than simple formal experimentation, since it usually challenges understandings of politics as well, i.e., the politics of perception, body, national memory, gender, cultural identity are represented in non-linear and fragmented ways (for specific instances see MIŠTEROVÁ's, KOWALCZE-PAWLIK's, REUSS's, and FABISZAK's essays in this collection). Whereas the Moving House Company subverted the well-known story line of Romeo and Juliet, and instead created a collective personal collage of representations of love, Viktor Bodó's directorial theatre has made use of various elements of adaptation, actor improvisation, and intermedial aesthetics, resulting in an altered story featuring ways love might be represented in a violent and non-poetic reality. Both stagings can be seen as representative ways of relocating the dramatic element in Hungarian theatre: Bodó's production through the dominance of visuality and music, the Moving House production through collective associations and experiences.

7 Ádám Nádasdy is one of the leading contemporary Hungarian translators of Shakespeare's dramas.

8 Translation by Péter Závada.

9 It is interesting to note that the change in Bodó's Hungarian reception can easily be connected to the point when he began working in established Austrian and German theatres as a guest director. 


\section{Bibliography}

BALME, Christopher. 2004. Intermediality: Rethinking the Relationship Between Theatre and Media. TheWis 1: Zeitschrift der Gesellschaft für Theaterwissenschaft (2004): 1: 1-18.

BOENISCH, Peter. 2003. coMEDIA electrONica. Theatre Research International 28 (2003): 1: 34-45. BOUCHARD, Gianna. 2008. 'Be not faithless but believing': Illusion and Doubt in Anatomy Theatre. In Maaike Bleeker (ed.). Anatomy Live: Performance and Operating Theatre. Amsterdam: Amsterdam University Press, 2008: 93-110.

CARDY, Tom. 2012. Audiences endure shock and bore. Stuff (7. 03. 2012). [accessed on 18.01.2021]. Available online at: http://www.stuff.co.nz/dominion-post/culture/6522466/ Audiences-endure-shock-and-bore.

CARLSON, Marvin. 2009. Theatre Is More Beautiful Than War: German Stage Directing in the Late Twentieth Century. Iowa City: University of Iowa Press, 2009.

CONSTANTINIDIS, Startos E. 1993. Theatre Under Deconstruction? A Question of Approach. New York: Garland, 1993.

CSÁKI, Judit. 1999. Feeling. Ellenfény 1 (1999): 45-46.

CSÁKI, Judit. 2003. Színészparádé blődliben [Foolish Parade of Actors]. Magyar Narancs (23. 10. 2003): 43.

DERES, Kornélia. 2016. Képkalapács: Színház, technológia, intermedialitás [Hammer for Images: Theatre, Technology, Intermediality]. Budapest: JAK-Prae, 2016.

GARDNER, Lyn. 2014. Lear-inspired Show Searingly Exposes Family Ties and Debts. The Guardian (4. 06. 2014). [accessed on 18.01.2021]. Available online at https://www.theguardian. com/stage/2014/jun/04/testament-she-she-pop-and-their-fathers-barbican-review.

IMRE, Zoltán. 2009. A színház szinpadra állitásai [Stagings of Theatre]. Budapest: Ráció, 2009.

KARSAI, György. 2005. Volt egyszer egy évad [Once there was a Season]. Színház 38 (2005): 5: 7.

KATTENBELT, Chiel. 2006. Theatre as the Art of the Performer and the Stage of Intermediality. In Freda Chapple and Chiel Kattenbelt (eds.). Intermediality in Theatre and Performance. Amsterdam: Rodopi, 2006: 29-40.

KOLTAI, Tamás. 1999. Úrt érzek [I Feel Emptiness]. Élet és Irodalom (5. 11. 1999): 17.

KONDOROSI, Zoltán. 2005. Összjátékok [Teamworks]. Ellenfény 4 (2005): 38-40.

KOVACS, Teresa. 2017. Elfriede Jelinek and Ewald Palmetshofer in between. Sedimentations, enclosures and overlayering of dramatic formations in contemporary German-language playwriting. In Zuzana Augustová, Jan Jiř́ík and Daniela Jobertová (eds.). Horizonty europského dramatu: Současný divadelni text mezi dramatickými a postdramatickými tendencemi [Horizons of the European Drama: A Contemporary Theatrical Text Between Dramatic and Postdramatic Tendencies]. Prague: Kosmas, 2017: 243-262.

LEHMANN, Hans-Thies. 2006. Postdramatic Theatre. Transl. by Karen Jürs-Munby. London and New York: Routledge, 2006.

MANCEWICZ, Anita. 2014. Intermedial Shakespeares on European Stages. London: Palgrave Macmillan, 2014.

MOLNÁR GÁL, Péter. 1999. Trafó-tragédia [Tragedy at Trafo]. Népszabadság (27. 11. 1999): 26. 
MOLNÁR GÁL, Péter. 2006. Don Blőd. Szinhaz.hu (7. 11. 2006). [accessed on 18.01.2021]. Available online at https://szinhaz.hu/2006/11/07/don_blod.

PERESZLÉNYI, Erika. 2014a. Hudi László: Rómeó és Júlia, 1996 [László Hudi: Romeo and Juliet, 1996]. Philther.hu. [accessed on 18.01.2021]. Available online at http://www.philther.hu/link/ play/romeo-es-julia-2/section/.

PERESZLÉNYI, Erika. 2014b. Hudi László: Tragédia-jegyzetek, 1999 [László Hudi: Tragedynotes, 1999]. Philther.hu. [accessed on 18.01.2021]. Available online at_http://www.philther. hu/link/play/tragedia-jegyzetek/section/.

PIKLI, Natália. 2013. The Prince and the Hobby-Horse: Shakespeare and the Ambivalence of Early Modern Popular Culture. Journal of Early Modern Studies 2 (2013): 119-140.

REYNOLDS, Bryan. 2017. Intermedial Theatre: Performance Philosophy, Transversal Poetics, and the Future of Affect. London: Palgrave Macmillan, 2017.

SCHÄFER, Martin Jörg. 2019. Translation as Entanglement. In Michaela Ott and Thomas Weber (eds). Situated in Translations: Cultural Communities and Media Practices. Bielefeld: transcript, 2019: 119-132.

SHUSTERMAN, Richard. 2012. Thinking Through the Body: Essays in Somaesthetics. Cambridge: Cambridge University Press, 2012.

SÓREGI, Melinda. 2002. Amint a léggömb kipukkad [As the Balloon Bursts]. Criticai Lapok (2002): 3.

SZABÓ, Attila. 2019. A valós színterei: Szinház, közösség, múltfeldolgozás [Stages of the Real: Theatre, Community, Past Procession]. Budapest: Prae, 2019.

TARJÁN, Tamás. 2007. Holdkór [Lunatic]. Szinház 40 (2007): 1: 9-11.

VAJNA, Tamás. 1996. Szükségből szerény [Humble out of Necessity]. HVG (20. 04. 1996): 101.

ZÁVADA, Péter. 2020. Kertész utcai Shaxpeare-mosó [The Shaxpeare Wash of Kertész Street], Manuscript. 


\section{Kornélia Deres}

Eötvös Loránd University - University of Cologne, Germany

deres.kornelia@btk.elte.hu

ORCID: https://orcid.org/0000-0002-5339-8855

Kornélia Deres is a lecturer at the Institute of Hungarian Literature and Cultural Studies of Eötvös University (ELTE), Budapest. In 2020/2021 she is a Humboldt Fellow at the Institute of Media Culture and Theatre of the University of Cologne. Her articles have been published in journals including Theatre Research International, New Theatre Quarterly, and Global Performance Studies. She is a co-editor of five books as well as the author of a monograph, Képkalapács [Hammer for Images] (2016) touching upon the issue of intermediality and theatre. She initiated the book series 'SzínText' including drama volumes and edited collections on theatre. 